\title{
Determination of best-fit isotherm model for the sorption of Lead (II) and Manganese (II) ions onto acid-activated shale using selected non-linear error functions
}

\author{
I. R. Ilaboya (1) a,*, J. S. Okpoko ${ }^{b}$ \\ ${ }^{a}$ Department of Civil Engineering, Faculty of Engineering, University of Benin, Benin City, Nigeria \\ ${ }^{b}$ Department of Civil Engineering, Benson Idahosa University, P. M. B. 1100, Benin City, Nigeria
}

\section{ARTICLE INFO}

\section{Article history:}

Received 27 April 2021

Received in revised form 2 June 2021

Accepted 6 June 2021

Available online

12 June 2021

Keywords:

Error functions

Freundlich isotherm

Isotherm model

Langmuir isotherm

Temkin isotherm

\begin{abstract}
The focus of this research is to apply the selected error function equation to establish the equilibrium isotherm model that best describes the adsorption of $\mathrm{Pb}^{2+}$ and $\mathrm{Mn}^{2+}$ onto acid-activated shale. Data collected from the batch experiment were analyzed using selected isotherm models (Langmuir, Freundlich, Temkin, DubininRadushkevich, Sips and Redlich-Peterson). To compute the isotherm parameters used in choosing the best-fit isotherm model, selected nonlinear error functions, namely, error sum of the square, normalized standard deviation, hybrid error function, root mean square error and Marquardt's percent standard deviation were employed. From the scanning electron microscope results, it was observed that the surface characteristics of the shale change considerably with calcination and acid treatment but the acid-treated shale shows better uneven porous surface characteristics. Error function computation shows that the Dubinin-Radushkevich isotherm model had the least sum of normalized error of 0.3623 for $\mathrm{Pb}^{2+}$ adsorption and 0.5465 for $\mathrm{Mn}^{2+}$ adsorption; hence, it was selected as the best isotherm model for explaining the sorption of $\mathrm{Pb}$ (II) and $\mathrm{Mn}$ (II) ions unto acid-activated shale.
\end{abstract}

\section{Introduction}

Environmental effluence toxic waste caused by the discharge of wastewater containing poisonous metals such as chromium, lead and manganese has been an issue of concern, which has become a widely studied area [1]. Unlike organic contaminants, which are mainly susceptible to biological degradation, heavy metals do not decompose into harmless end products. In addition, their occurrence in the environment can lead to bioaccumulation in living organisms, which can cause health problems [2].
Lead, chromium, and manganese are poisonous to the human bio-system and are among the popular worldwide pollutants arising from increasing industrialization [3]. These metals are used in most chemical industries for the manufacture of dry cell batteries, leather tanning, electroplating, and corrosion control [4]. Many of these metals find their way into surface and groundwater systems by direct fallout or via runoff from streams and infiltration [5].

\footnotetext{
* Corresponding author E-mail address: rudolph.ilaboya@uniben.edu https://doi.org/10.37121/jase.v5i1.159
}

2636-607X / 2736-0652 @ 2021 the authors. Published by Sciengtex. This is an open access article under CC BY-NC-ND license (http://creativecommons.org/licenses/by-nc-nd/4.0/) 


\begin{tabular}{|c|c|c|c|}
\hline \multicolumn{4}{|c|}{ Constants' Identification } \\
\hline \multirow[t]{2}{*}{$A$} & \multirow{2}{*}{$\begin{array}{l}\text { Redlich-Peterson adsorption capacity } \\
\text { constant }\left(=b_{R P} q_{m}\right),(L / g)\end{array}$} & NSD & Normalized standard deviation \\
\hline & & $p$ & Number of isotherm parameters \\
\hline \multirow{3}{*}{$\begin{array}{l}a_{\mathrm{s}} \\
B\end{array}$} & \multirow{2}{*}{$\begin{array}{l}\text { Sips isotherm model constant }(\mathrm{L} / \mathrm{g}) \\
\text { Redlich-Peterson isotherm constant }\end{array}$} & $\overline{q_{c a l}}$ & The average value of calculated metal \\
\hline & & & uptake concentrations $(\mathrm{mg} / \mathrm{g})$ \\
\hline & $\left(\mathrm{L} / \mathrm{mg}^{1-1 / \mathrm{A}}\right)$ & $q_{\text {cal }}$ & Equilibrium capacity obtained by \\
\hline \multirow[t]{2}{*}{$b_{\mathrm{RP}}$} & \multirow{2}{*}{$\begin{array}{l}\text { Parameter of Redlich-Peterson isotherm } \\
\text { equation }\left(\mathrm{L} / \mathrm{mg}^{1-1 / \mathrm{A}}\right)\end{array}$} & & calculating from the model $(\mathrm{mg} / \mathrm{g})$ \\
\hline & & $q_{e}$ & Equilibrium metal uptake concentrations \\
\hline \multirow[t]{2}{*}{$b_{\top}$} & \multirow{2}{*}{$\begin{array}{l}\text { Temkin isotherm constant related to } \\
\text { adsorbent-adsorbate interactions }(\mathrm{J} / \mathrm{mol})\end{array}$} & & $(\mathrm{mg} / \mathrm{g})$ \\
\hline & & $q_{\text {exp }}$ & Experimental data of the equilibrium \\
\hline$C_{0}$ & Initial metal ion concentrations (mg/L) & & capacity $(\mathrm{mg} / \mathrm{g})$ \\
\hline \multirow[t]{2}{*}{$C_{\mathrm{e}}$} & \multirow{2}{*}{$\begin{array}{l}\text { Equilibrium metal ion concentrations } \\
(\mathrm{mg} / \mathrm{L})\end{array}$} & $\mathrm{q}_{\mathrm{m}}$ & Maximum adsorption capacity $(\mathrm{mg} / \mathrm{g})$ \\
\hline & & $\mathrm{q}_{\mathrm{mDR}}$ & Saturation capacity for Dubinin- \\
\hline$g$ & An exponent between 0 and 1 & & Radushkevich (mg/g) \\
\hline HYBRID & Hybrid fractional error function & $\mathrm{R}$ & Universal gas constant $(\mathrm{J} / \mathrm{mol} / \mathrm{K})$ \\
\hline \multirow[t]{2}{*}{$K_{\mathrm{DR}}$} & \multirow{2}{*}{$\begin{array}{l}\text { Dubinin-Radushkevich Constant indicative } \\
\text { of adsorption energy }\left(\mathrm{mol}^{2} / \mathrm{kJ}\right)\end{array}$} & $\mathrm{R}^{2}$ & Coefficient of determination \\
\hline & & RMSE & Root mean square error \\
\hline \multirow[t]{2}{*}{$K_{\mathrm{F}}$} & \multirow{2}{*}{$\begin{array}{l}\text { Freundlich isotherm constant indicative of } \\
\text { adsorption capacity }\left(\mathrm{mg}^{1-(1 / \mathrm{n})} \mathrm{L}^{1 / \mathrm{n}} / \mathrm{g}\right)\end{array}$} & SEM & Scanning electron microscope \\
\hline & & SNE & Sum of normalized error \\
\hline$K_{\mathrm{L}}$ & Langmuir isotherm constant (L/mg) & SSE & Sum of square error \\
\hline$K_{\mathrm{s}}$ & Sips isotherm model constant (L/mg) & $\mathrm{T}$ & Absolute temperature $(\mathrm{K})$ \\
\hline$K_{\mathrm{T}}$ & Temkin equilibrium binding constant (L/g) & $V$ & Aqueous sample volume (ml) \\
\hline$m$ & Mass of adsorbent used $(\mathrm{g})$ & $\mathrm{XRF}$ & X-ray fluorescence \\
\hline MPSD & Marquardt's percent standard deviation & \multicolumn{2}{|c|}{ Greek letters } \\
\hline$n$ & Adsorption intensity & & \\
\hline $1 / n_{s}$ & Sips model exponent & $\beta_{\mathrm{s}}$ & SIps Isotherm exponent \\
\hline$N$ & Number of experimental data points & $\varepsilon$ & Polanyi potential \\
\hline NE & Normalized error & $\eta$ & Efficiency (\%) \\
\hline
\end{tabular}

The absorption of fairly small quantities of these heavy metals over an elongated period by humans can lead to protracted toxicity together with several health challenges such as skin irritation, lung tumor and circulatory system [6]. The venomous effects of chromium, lead, and manganese ions in humans particularly when present above the threshold boundary in the hydrosphere is alarming and well documented [7]. The presence of these metals in the ecosystem is of great concern to engineers and scientists because of their harmful nature as well as other adverse impacts posed by the discharge of untreated effluents containing such metals on receiving water bodies [8].

Physico-chemical processes that have been employed in the treatment of wastewater containing heavy metals before being discharged into water bodies include chemical and electrolytic precipitation, reverse osmosis, electrodialysis, and ion exchange methods [9]. Adsorption offers good prospects over other treatment techniques owing to its flexibility and ease of operation [10]. Adsorption is a process that involves the movement of molecules of the fluid phase (liquid or gas) to the surface of the solid. In adsorption, liquid or gas molecules diffuse from the bulk solution to the surface of the solid forming an adsorbed phase of distinct characteristics [11-12].

Over the years, linear transformation of the isotherm equations coupled with the application of the least square regression method to compute the $\mathrm{R}^{2}$-value, remains the most widely used technique. Because of this, the isotherm model having an $\mathrm{R}^{2}$-value closer to one was selected as the best-fit isotherm model [13-14]. Determination of $\mathrm{R}^{2}$-value and its subsequent application in the selection of best-fit isotherm model is not satisfactory owing to the alteration in the error structure associated with the transformation of the nonlinear isotherm equation to its linear form. In addition, $\mathrm{R}^{2}$-value only accounts for the difference associated with each point fitted by the model concerning the overall average of the fitted curve.

Therefore, to have an accurate judgment in the selection of the best-fit isotherm model, non-linear error functions were employed. Error functions such as SSE, NSD, HYBRID, RMSE, and MPSD unlike $\mathrm{R}^{2}$, accounts for the 
difference associated with each point fitted by the model concerning each experimental point measured. Furthermore, since each of the selected error functions produced nonidentical sets of isotherm constraints, an overall optimal isotherm parameter set was hard to find directly. To overcome this limitation and make a more significant comparison between the parameter sets, a technique for normalizing the computed error functions was assumed to produce a single combination of the minimized error called the SNE for each selected isotherm parameter [15].

In this paper, selected non-linear error functions and their subsequent minimization using the SNE was utilized to determine the isotherm model that best describes the adsorption of $\mathrm{Pb}^{2+}$ and $\mathrm{Mn}^{2+}$ onto acidactivated shale.

\section{Methodology}

\subsection{Collection and Preparation of Adsorbent}

Shale was extracted from its deposit in Okada. To remove any carbonaceous matter, which could interfere with the shale's metal adsorption capability, the shale was first soaked in a plastic containing $5 \% \mathrm{H}_{2} \mathrm{O}_{2}$. It was then treated with purified water to eliminate any water-soluble impurities before being used. The dried shale was then finely ground and sieved with a $212 \mathrm{~m}$ sieve before being used according to Krishna and Susmita [16]. $500 \mathrm{~g}$ of dried sieved shale was calcined in a furnace at $550{ }^{\circ} \mathrm{C}$ for $10 \mathrm{~h}$ before being put in a desiccator to cool before using. Acid activation was achieved by mixing $200 \mathrm{~g}$ of calcinated shale with 1 liter of $\mathrm{H}_{2} \mathrm{SO}_{4}(0.25 \mathrm{M})$. Before use, the shale was dried for 30-45 min at $100{ }^{\circ} \mathrm{C}$, ground with a mortar and pestle, sieved to $212 \mathrm{~m}$, and stored in a desiccator.

\subsection{Characterization of Adsorbent}

To characterize the shale material for use as an adsorbent, a SEM and an XRF were employed to assess the microstructural arrangement and the chemical composition of the shale material after acid-activation [1718].

\subsection{Preparation of Aqueous Solution}

To prepare the adsorbate, a stock solution of lead (II) nitrate and manganese (II) chloride tetrahydrate were employed. The salts were dissolved in 1 liter of distilled water and stirred to mix. The required concentration of adsorbate was prepared by further diluting the stock solution while the metal ion concentration was determined with the aid of atomic absorption spectrophotometer. To regulate the $\mathrm{pH}$ of the solution, dropwise addition of $\mathrm{HNO}_{3}(1 \mathrm{M})$ or $\mathrm{NaOH}(1 \mathrm{M})$ was adopted.

\subsection{Adsorption Studies}

Adsorption studies were conducted to investigate the effects of selected adsorption variables, namely; adsorption temperature, contact time, adsorbent dose, and $\mathrm{pH}$. A mixture of varying doses of adsorbent and 50 $\mathrm{ml}$ adsorbate solution was stirred at $150 \mathrm{rpm}$ for diverse contact times and constant $\mathrm{pH}$. Separation of the adsorbent from the adsorbate solution of heavy metal was achieved with the aid of filtration process using $150 \mathrm{ml}$ Whatman filter paper while the residual metal ions removed during the process was deduced using the proposed mass balance equation by Badmus et al. [3]:

$q_{e}=\frac{V}{m}\left[C_{0}-C_{e}\right]$

Where, $q$ defines the equilibrium metal uptake concentration $(\mathrm{mg} / \mathrm{g}) ; C_{0}$ and $C_{e}$ are the initial and equilibrium metal ion concentrations $(\mathrm{mg} / \mathrm{l}), V$ is the aqueous sample volume $(\mathrm{ml})$ and $m$ is the mass of adsorbent used $(g)$.

The efficiency $(\eta)$ of metal ion removal was calculated using the mass balance equation of the form expressed in equation (2) [3].

$\eta=\left(\frac{C_{0}-C_{e}}{C_{0}} \times 100\right)$

\subsection{Equilibrium Isotherm Studies}

To study the equilibrium relationship between the amount of metal ions removed and the amount of metal ions remaining, batch experimental data were analyzed using selected linear isotherm models presented in Table 1.

\subsection{Error Analysis}

Linear regression analysis can be used to specify the best-fitting correlation, which quantifies the distribution of adsorbates as well as validation of the consistency of the theoretical adsorption models. Nevertheless, the error structure of measured or experimental dataset normally varied during the linear transformation of adsorption isotherms [28]. As a consequence, nonlinear regression analysis gives a statistically rigorous approach for establishing adsorption parameters [29]. Nonlinear regression typically entails the minimization of error distribution between the computed isotherm and measured data based on its convergence criteria [26]. The selected error functions utilized are presented in Table 2. 
Table 1 Linear isotherm equations.

\begin{tabular}{ccc}
\hline Isotherm model & Definition & Equation \\
\hline Langmuir [19] & $\frac{C_{e}}{q_{e}}=\frac{1}{q_{m}} \cdot C_{e}+\frac{1}{q_{m} K_{L}}$ \\
Freundlich [20] & $\ln q_{e}=\frac{1}{n} \ln C_{e}+\ln K_{F}$ \\
Temkin [21] & $\mathrm{q}=\mathrm{a}+\mathrm{b} \ln \mathrm{C}_{\mathrm{e}}$
\end{tabular}

Table 2 Definition of selected error functions.

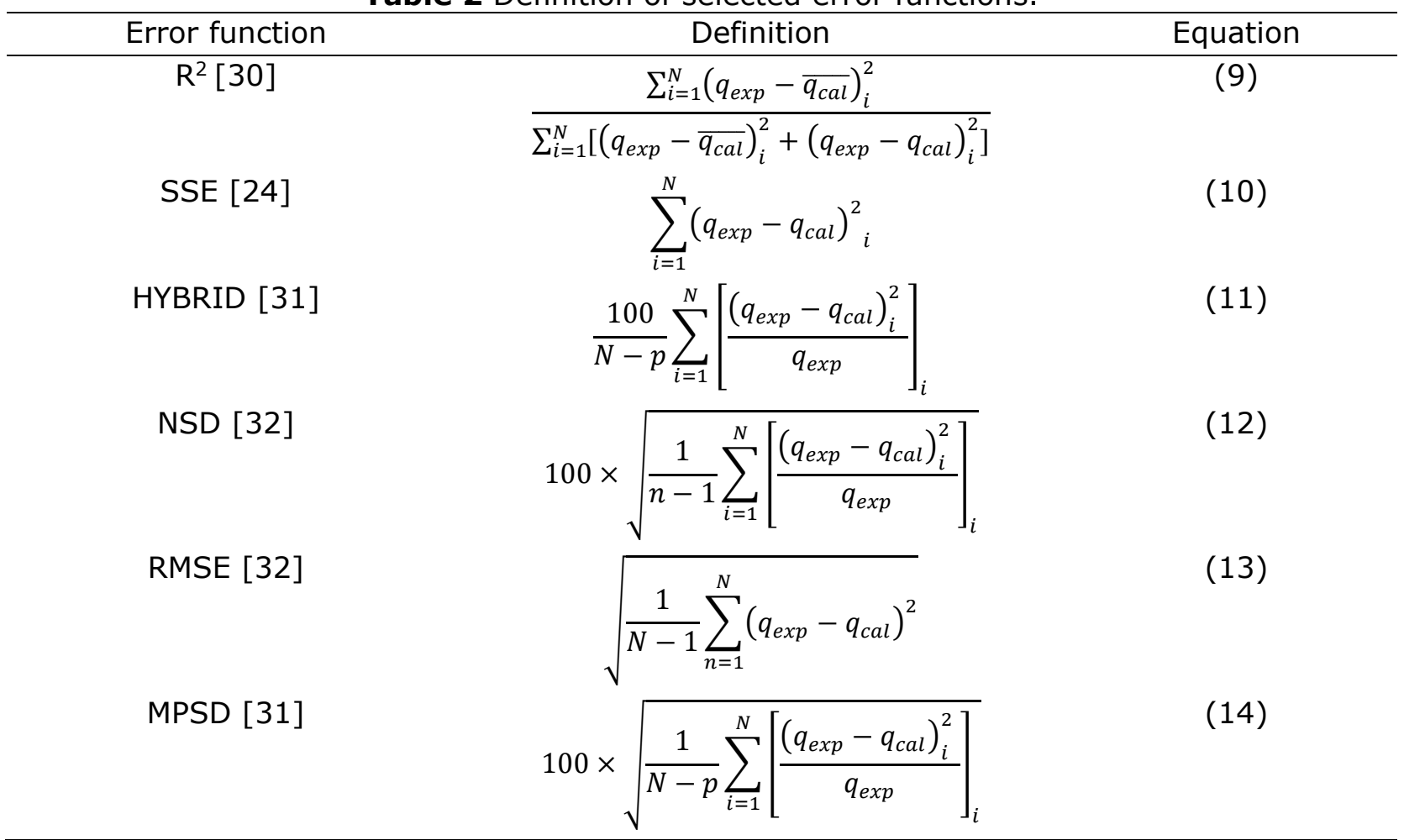

\section{Results and Discussion}

\subsection{Adsorbent Characterization}

Results of adsorbent characterization are shown in Fig. 1 and Table 3. A SEM was used to confirm the existence of microspores in the shale structure. The surface properties of the shale materials change dramatically with calcination and acid treatment, as shown in Fig. 1(a)-(c), with the acid-treated shale having a stronger random porous surface structure. From the chemical analysis of the shale material, it was observed that the dominant oxides found in shale were aluminum oxide and silicon oxide. The alumina content of raw shale was found to be 21.33 weight percent, rising to 24.41 weight percent for calcinated shale and decreasing to 18.13 weight percent for acid-activated shale, presumably due to the shale's acid dealumination caused by acidification.

From the results of Fig. 1 (a)-(c), it was observed that acid treated shale showed more porous surface characteristics than the raw and calcinated shales. The reason being that acid treatment tends to open up the pore spaces better than calcination alone. The higher number of microporous structures seen with acid-activated shale indicates a greater surface area. This assertion is due to the fact that as bio-sorbent materials present larger numbers of microporous structure, it adsorbs greater amount of nitrogen, which resulted to a higher surface area. 


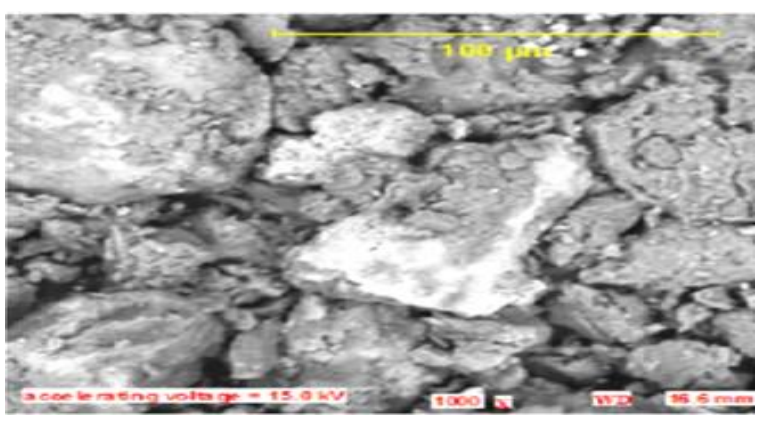

(a)

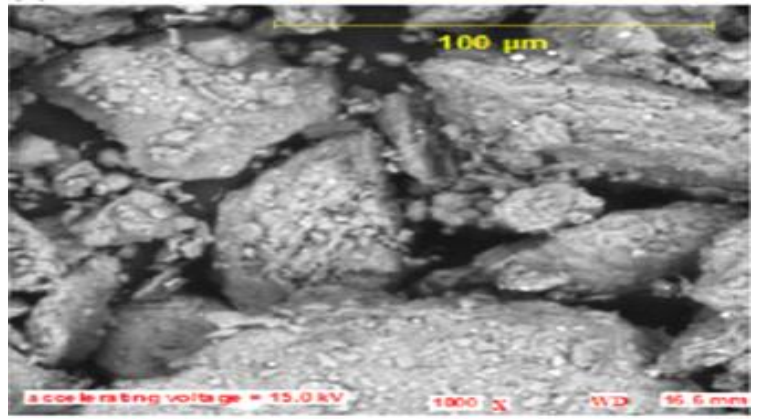

(b)

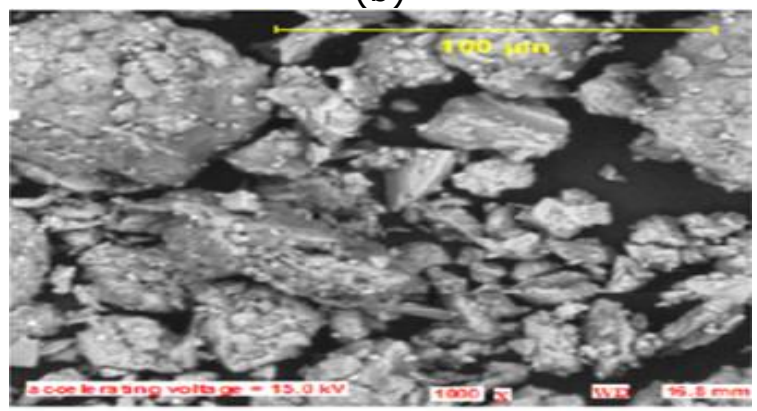

(c)

Fig. 1 SEM (a) raw shale, (b) calcinated shale, and (c) acid-activated shale.

\subsection{Adsorption Isotherm Modeling}

The adsorption isotherm models were fitted to explain the relationship between the adsorbate and adsorbent materials thus providing relevant data that can be useful in assessing the adsorption potential of the adsorbents. Results of the two parameters isotherm modeling are presented in Fig. 2 . When the sorption data were analyzed based on the linear form of the Langmuir isotherm model presented in Fig. 2(a), it was observed based on the $\mathrm{R}^{2}$-value that Langmuir isotherm produces a very strong fit for the sorption of $\mathrm{Pb}$ (II) and $\mathrm{Mn}$ (II) onto acid-activated shale.

The linear Freundlich isotherm graph presented in Fig. 2(b), appears to produce a reasonable fit for sorption in all two systems with $\mathrm{Mn}$ (II) ion adsorption showing a better fit than $\mathrm{Pb}$ (II) ions adsorption. Analysis of sorption data based on the linear form of Temkin isotherm model presented in Fig. 2(c), revealed the suitability of the Temkin isotherm model in providing a reasonable fit for the
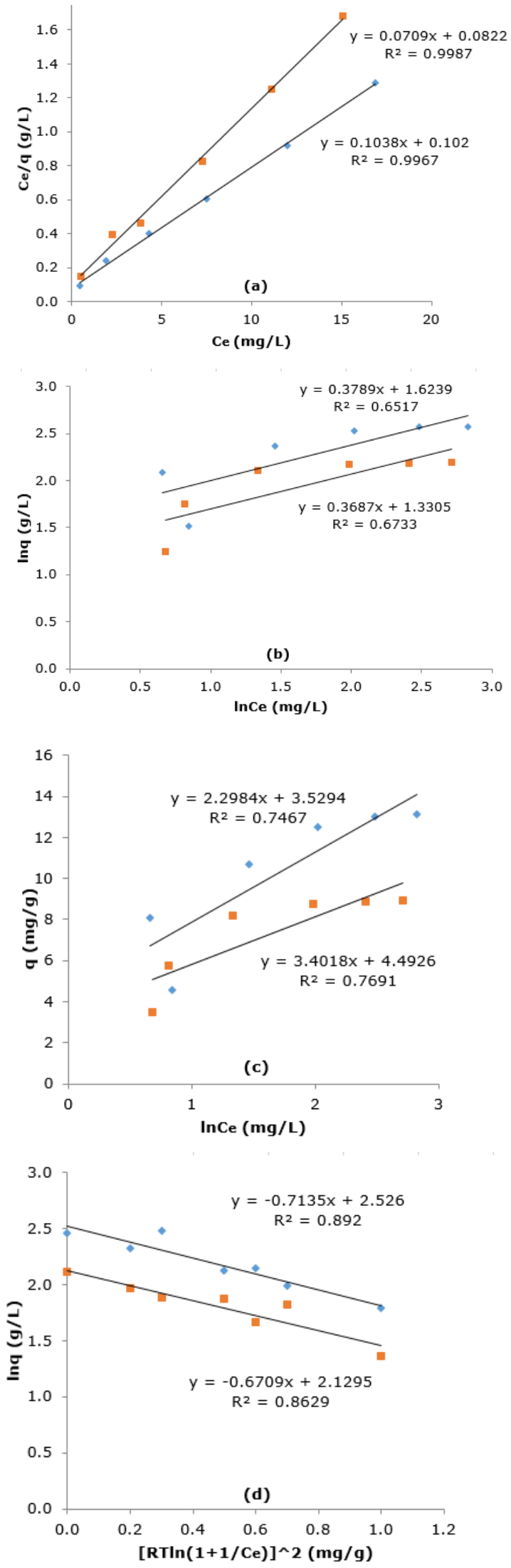

- $\mathrm{Pb}(\mathrm{II})$ ion adsorption onto acid-activated shale $=\mathrm{Mn}$ (II) ion adsorption onto acid-activated shale

Fig. 2 Isotherm models for $\mathrm{Pb}$ (II) and $\mathrm{Mn}$ (II) ions adsorption (a) Langmuir, (b) Freundlich, (c) Temkin, and (d) Dubinin-Raduskevich. 
sorption of $\mathrm{Pb}$ (II) and $\mathrm{Mn}$ (II) onto acidactivated shale with $\mathrm{Mn}$ (II) ion adsorption showing better fit compared to the adsorption of $\mathrm{Pb}$ (II). More also, the results of Fig. 2(d), showed that the linear form of the DubininRadushkevich isotherm model can also provide a good fit for sorption in all two systems.

The simplicity of the two-parameter isotherm model in providing a reasonable fit to adsorption data was based on the fact that the model variables can easily be transformed so that the overall equation was converted to a linear form for which linear regression can then be applied. These transformations do not seem to be possible with three-parameter isotherms such as the Sips and RedlichPeterson isotherm model. Based on this, a trial-and-error method was introduced to determine one of the constraints thus paving way for the application of linear regression analysis. Since the transformation of nonlinear to linear equations indirectly modifies their error structure and can also violate the error variance, alternative isotherm parameter sets were determined by non-linear regression analysis using the non-linear form of the isotherm equation.

Table 3 Predicted isotherm by minimizing the error distribution using different error functions for $\mathrm{Pb}$ (II) ion adsorption onto acid activated shale.

\begin{tabular}{|c|c|c|c|c|c|}
\hline Langmuir & $q_{\mathrm{e}}$ & $K_{\mathrm{L}}$ & OFa $^{a}$ & $\mathrm{NE}$ & $\mathrm{SNE}=1.1774$ \\
\hline $\mathrm{R}^{2}$ & 11.7191 & 2.9741 & 1.000 & 0.2538 & \\
\hline SSE & 10.9513 & 3.1491 & $1.366 \mathrm{E}-08$ & 0.2875 & \\
\hline HYBRID & 13.4747 & 1.9878 & $1.420 \mathrm{E}-11$ & 0.1475 & \\
\hline NSD & 13.3833 & 2.4345 & $4.417 \mathrm{E}-08$ & 0.1819 & \\
\hline RMSE & 13.5848 & 2.2300 & 5.153E-09 & 0.1642 & \\
\hline MPSD & 13.3970 & 1.9226 & 1.029E-06 & 0.1435 & \\
\hline Freundlich & $K_{\mathrm{F}}$ & $1 / n$ & $\mathrm{OF}^{a}$ & NE & SNE $=3.7953$ \\
\hline $\mathrm{R}^{2}$ & 2.4588 & 1.0000 & 1.000 & 0.4067 & \\
\hline SSE & 3.1620 & 0.8985 & $3.669 E-08$ & 0.2842 & \\
\hline HYBRID & 1.1106 & 1.0000 & $1.357 \mathrm{E}-30$ & 0.9004 & \\
\hline NSD & 1.6057 & 1.0177 & $4.498 \mathrm{E}-06$ & 0.6338 & \\
\hline RMSE & 1.5926 & 0.9432 & $7.167 E-07$ & 0.5922 & \\
\hline MPSD & 1.0259 & 1.0033 & $2.153 E-06$ & 0.9780 & \\
\hline Temkin & $K_{\mathrm{T}}$ & $b_{\mathrm{T}}$ & $\mathrm{OF}^{a}$ & $\mathrm{NE}$ & SNE $=3.8129$ \\
\hline $\mathrm{R}^{2}$ & 3.6137 & 4.8903 & 1.000 & 0.7390 & \\
\hline SSE & 3.9229 & 4.7683 & 5.493E-08 & 0.8227 & \\
\hline HYBRID & 2.2704 & 4.2016 & $1.383 \mathrm{E}-30$ & 0.5404 & \\
\hline NSD & 2.8847 & 4.8299 & $3.495 E-06$ & 0.5973 & \\
\hline RMSE & 2.6387 & 4.6420 & $1.495 \mathrm{E}-08$ & 0.5684 & \\
\hline MPSD & 2.3479 & 4.3072 & $1.023 E-08$ & 0.5451 & \\
\hline Dubinin-Radushkevich & $q_{\mathrm{mDR}}$ & $K_{\mathrm{DR}}$ & $\mathrm{OF}^{\mathrm{a}}$ & NE & SNE $=0.3623$ \\
\hline $\mathrm{R}^{2}$ & 11.1568 & 0.5789 & 1.000 & 0.0519 & \\
\hline SSE & 10.3021 & 0.3844 & $7.466 \mathrm{E}-09$ & 0.0373 & \\
\hline HYBRID & 12.9970 & 0.9184 & $6.808 \mathrm{E}-18$ & 0.0707 & \\
\hline NSD & 12.8588 & 0.8214 & $2.782 E-06$ & 0.0639 & \\
\hline RMSE & 13.0756 & 0.8728 & $1.091 \mathrm{E}-09$ & 0.0667 & \\
\hline MPSD & 12.9306 & 0.9290 & $7.652 E-10$ & 0.0718 & \\
\hline Sips & $q_{0}$ & $b$ & $n$ & $\mathrm{OF}^{\mathrm{a}}$ & SNE $=2.4933$ \\
\hline$R^{2}$ & 1.8180 & 0.9219 & 0.9631 & 1.000 & \\
\hline SSE & 1.7725 & 0.8196 & 1.1548 & $3.712 \mathrm{E}-08$ & \\
\hline HYBRID & 1.8527 & 0.9307 & 0.6448 & $2.195 \mathrm{E}-16$ & \\
\hline NSD & 1.8320 & 0.9086 & 0.7856 & $8.436 \mathrm{E}-07$ & \\
\hline RMSE & 1.8357 & 0.9072 & 0.7274 & $1.729 \mathrm{E}-06$ & \\
\hline MPSD & 1.8369 & 0.8956 & 0.6434 & $2.202 \mathrm{E}-06$ & \\
\hline Redlich-Peterson & $A$ & B & $g$ & $\mathrm{OF}^{\mathrm{a}}$ & SNE $=1.3467$ \\
\hline $\mathrm{R}^{2}$ & 1.7294 & 0.7294 & 1.000 & 1.000 & \\
\hline SSE & 1.9068 & 0.9137 & 0.9596 & 3.632E-09 & \\
\hline HYBRID & 1.0553 & 0.0553 & 1.000 & $1.437 \mathrm{E}-30$ & \\
\hline NSD & 1.3729 & 0.2926 & 0.9983 & $9.906 \mathrm{E}-07$ & \\
\hline RMSE & 1.2041 & 0.1997 & 0.9996 & $2.504 \mathrm{E}-07$ & \\
\hline MPSD & 1.0197 & 0.0146 & 1.0038 & $7.752 \mathrm{E}-06$ & \\
\hline
\end{tabular}

$\mathrm{OF}^{\mathrm{a}}$ : Objective function for the minimum error distribution between experimental and predicted isotherm 
Table 4 Predicted isotherm by minimizing the error distribution using different error functions for $\mathrm{Mn}(\mathrm{II})$ ion adsorption onto acid activated shale.

\begin{tabular}{|c|c|c|c|c|c|}
\hline Langmuir & $q_{\mathrm{e}}$ & $K_{\mathrm{L}}$ & $\mathrm{OF}^{\mathrm{a}}$ & $\mathrm{NE}$ & SNE $=1.4469$ \\
\hline $\mathrm{R}^{2}$ & 8.4117 & 2.5745 & 1.0000 & 0.3061 & \\
\hline SSE & 7.7417 & 2.7483 & $1.029 \mathrm{E}-09$ & 0.3550 & \\
\hline HYBRID & 9.2649 & 1.6942 & $8.232 \mathrm{E}-12$ & 0.1829 & \\
\hline NSD & 9.6035 & 2.1170 & $4.103 \mathrm{E}-08$ & 0.2204 & \\
\hline RMSE & 9.5870 & 1.9337 & $6.801 \mathrm{E}-09$ & 0.2017 & \\
\hline MPSD & 9.1548 & 1.6552 & $6.398 \mathrm{E}-08$ & 0.1808 & \\
\hline Freundlich & $K_{\mathrm{F}}$ & $1 / n$ & OFa & $\mathrm{NE}$ & SNE $=4.2156$ \\
\hline $\mathrm{R}^{2}$ & 2.0534 & 1.0000 & 1.0000 & 0.4870 & \\
\hline SSE & 2.3534 & 1.0051 & $3.797 \mathrm{E}-08$ & 0.4271 & \\
\hline HYBRID & 0.8058 & 1.0000 & $1.994 \mathrm{E}-30$ & 0.8058 & \\
\hline NSD & 1.4323 & 0.9503 & $2.204 \mathrm{E}-05$ & 0.6635 & \\
\hline RMSE & 1.0491 & 1.0058 & $3.210 \mathrm{E}-07$ & 0.9587 & \\
\hline MPSD & 1.0047 & 0.8776 & $3.781 \mathrm{E}-06$ & 0.8735 & \\
\hline Temkin & $K_{\mathrm{T}}$ & $b_{\mathrm{T}}$ & $\mathrm{OF}^{\mathrm{a}}$ & $\mathrm{NE}$ & $\mathrm{SNE}=4.3056$ \\
\hline $\mathrm{R}^{2}$ & 2.9517 & 3.5577 & 1.0000 & 0.8297 & \\
\hline SSE & 3.2498 & 3.4015 & 7.020E-09 & 0.9554 & \\
\hline HYBRID & 1.7437 & 2.8297 & 0.0000 & 0.6162 & \\
\hline NSD & 2.2790 & 3.4718 & $2.062 \mathrm{E}-07$ & 0.6564 & \\
\hline RMSE & 2.0560 & 3.2609 & $1.547 \mathrm{E}-08$ & 0.6305 & \\
\hline MPSD & 1.8048 & 2.9230 & $1.125 \mathrm{E}-08$ & 0.6174 & \\
\hline Dubinin-Radushkevich & $q_{\mathrm{mDR}}$ & $K_{\mathrm{DR}}$ & $\mathrm{OF}^{\mathrm{a}}$ & $\mathrm{NE}$ & SNE $=0.5465$ \\
\hline $\mathrm{R}^{2}$ & 7.8820 & 0.6065 & 1.0000 & 0.0769 & \\
\hline SSE & 7.1659 & 0.4648 & $1.888 \mathrm{E}-09$ & 0.0649 & \\
\hline HYBRID & 8.8531 & 0.9396 & $1.849 \mathrm{E}-19$ & 0.1061 & \\
\hline NSD & 9.1287 & 0.8448 & 2.993E-06 & 0.0925 & \\
\hline RMSE & 9.1381 & 0.8950 & $2.433 \mathrm{E}-09$ & 0.0979 & \\
\hline MPSD & 8.7611 & 0.9479 & $1.701 \mathrm{E}-06$ & 0.1082 & \\
\hline Sips & $q_{0}$ & $b$ & $n$ & $\mathrm{OF}^{\mathrm{a}}$ & $\mathrm{SNE}=2.2295$ \\
\hline$R^{2}$ & 1.7561 & 0.8649 & 0.8862 & 1.0000 & \\
\hline SSE & 1.7089 & 0.7626 & 1.1271 & $9.394 \mathrm{E}-07$ & \\
\hline HYBRID & 1.8146 & 0.8832 & 0.5285 & $5.398 \mathrm{E}-10$ & \\
\hline NSD & 1.7972 & 0.8794 & 0.6705 & $2.538 \mathrm{E}-06$ & \\
\hline RMSE & 1.8015 & 0.8717 & 0.6112 & $2.580 \mathrm{E}-09$ & \\
\hline MPSD & 1.8076 & 0.8649 & 0.5190 & $3.570 \mathrm{E}-06$ & \\
\hline Redlich-Peterson & $A$ & $B$ & $g$ & $\mathrm{OF}^{\mathrm{a}}$ & SNE $=0.9067$ \\
\hline $\mathrm{R}^{2}$ & 1.5267 & 0.5267 & 1.0000 & 1.0000 & \\
\hline SSE & 1.7160 & 0.6935 & 0.9396 & $6.088 \mathrm{E}-09$ & \\
\hline HYBRID & 0.8058 & 0.0000 & 1.0000 & 0.0000 & \\
\hline NSD & 1.1518 & 0.1488 & 1.0021 & $3.745 \mathrm{E}-10$ & \\
\hline RMSE & 1.0328 & 0.0289 & 1.0091 & 4.347E-08 & \\
\hline MPSD & 0.7431 & 0.0004 & 1.0001 & $5.472 \mathrm{E}-07$ & \\
\hline
\end{tabular}

$O^{a}$ : Objective function for the minimum error distribution between experimental and predicted isotherm

To perform the non-linear regression and estimate the isotherm parameters, a solver add-in with Microsoft's Excel spreadsheet was employed. Since each of the selected error functions produced non-identical sets of isotherm parameters, an overall optimal isotherm parameter set was difficult to identify directly. To overcome this limitation and make a more meaningful comparison between the parameter sets, a procedure of normalizing the computed error functions was adopted to produce a single combination of the minimized error called SNE for each selected isotherm parameter [33]. The SNE was thereafter employed to choose the isotherm that best described the adsorption of
$\mathrm{Pb}^{2+}$ and $\mathrm{Mn}^{2+}$ onto acid-activated shale since the lower the sum of normalized error, the better the ability of the isotherm to describe the adsorption data. Results of the predicted isotherm by minimizing the error distribution using the selected error functions are presented in Tables 3 and 4 representing $\mathrm{Pb}^{2+}$ and $\mathrm{Mn}^{2+}$ adsorption onto shale. To select the isotherm model that best explains the adsorption data for specific metal ion removal, a graphical relationship between the computed SNE and the selected isotherm model for the sorption of $\mathrm{Pb}$ (II) and $\mathrm{Mn}$ (II) ion onto acid-activated shale were obtained and presented in Fig. 3. 

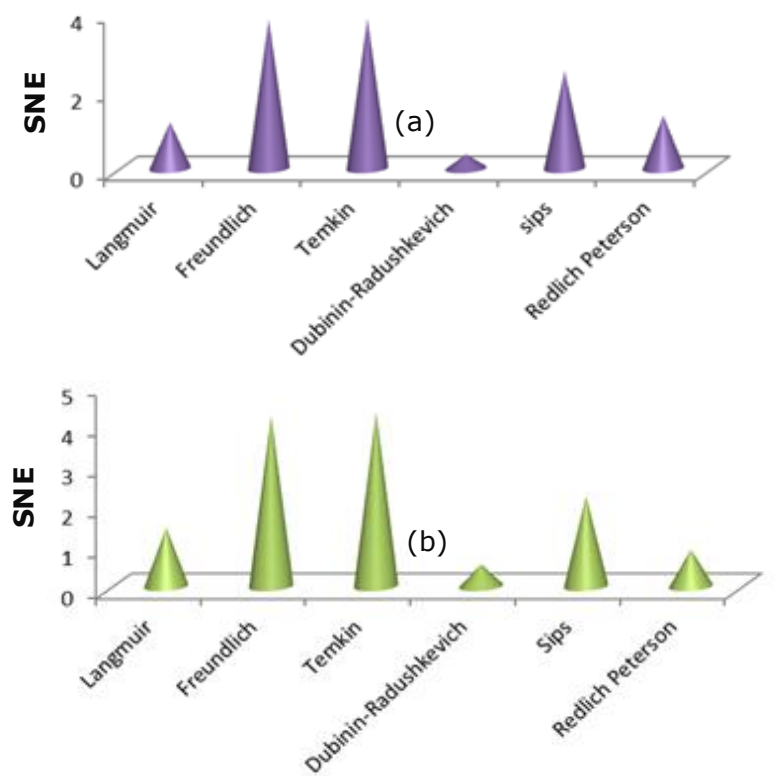

Fig. 3 Selection of best-fit isotherm for (a) $\mathrm{Pb}$ (II) ion adsorption and (b) Mn(II) ion adsorption.

From the results of Fig. 3, it was noted that the Dubinin-Radushkevich isotherm model was the most suitable model to satisfactorily described the sorption of $\mathrm{Pb}^{2+}$ and $\mathrm{Mn}^{2+}$ onto acid-activated shale. Based on these findings, the sorption capacity of acid-activated shale was taken as $11.1568 \mathrm{mg} / \mathrm{g}$. The average free energy of sorption per mole of the sorbate (E) as it is transferred to the surface of the solid from infinite distance in the solution was deduced using $E=1 / \sqrt{2 K_{D R}}=0.9294 \mathrm{~kJ} / \mathrm{mol}$; where $K_{D R}=0.5789$, the positive value indicates endothermic reaction.

\section{Conclusion}

The application of non-linear error function for the selection of isotherm model that best explained the experimental data for the sorption of $\mathrm{Pb}^{2+}$ and $\mathrm{Mn}^{2+}$ onto acid-activated shale has been investigated. Based on the computed SNE, it was observed that the Dubinin-Radushkevich model provides the best-fit for the experimental data. Isotherm modeling using error function analysis is relevant in studying the potentials of materials as suitable adsorbents for water and wastewater treatment. It will also help determine the sorption capacity of adsorbents.

\section{Conflict of Interests}

The authors declare that there is no conflict of interests regarding the publication of this paper.

\section{ORCID}

I. R. Ilaboya (iD https://orcid.org/0000-0002-8982-7404

\section{References}

[1] S. B. Lalvani, T. Wiltowski, and A. Weston, "Metal ions removal from wastewater by adsorption," ACS, Division of Fuel Chemistry, vol. 42, no. 3, 877-879, 1997.

[2] S. Ong, C. Seng, and P. Lim, "Kinetics of adsorption of copper (II) and cadmium (II) from aqueous solution on rice husk and modified rice husk," Elec. J. Env. Agricult. Food Chem., vol. 6, no. 2, pp. 1764-1774, 2007.

[3] M. A. O. Badmus, T. O. K Audu, and B. U. Anyata, "Removal of lead ion from industrial wastewaters by activated carbon prepared from periwinkle shells (Typanotonus fuscatus)," Turkish J. Eng. Environ. Sci., vol. 31, pp. 251-263, 2007.

[4] G. Ziemacki, G. Viviano, and F. Merli, "Heavy metals: sources and environmental presence," Ann. 1st Super Sanita, vol. 25, no. 3, pp. 531-536, 1989

[5] P. Venugopala Rao, Text book of Environmental Engineering, Prentice - hall of India private limited, New Delhi, pp. 86-88, 2004.

[6] Drinking Water Inspectorate, "Guardians of drinking water quality; what are the drinking water standards?", 2014, http//www.dwi.gov.uk (accessed Jun 2, 2021)

[7] S. J. Khurshid, and I. H. Qureshi, "The role of inorganic elements in the human body," Nucleus, vol. 21, no. 4, pp. 3 - 23, 1984.

[8] M. Sekar, V. Sakthi, and S. Rengaraj, "Kinetics' and equilibrium studies of lead (II) onto activated carbon prepared from coconut shell," J. Colloid Interface Sci., vol. 279, pp. 307-313, 2004.

[9] V. K. Gupta, C. K. Jain, I. Ali, M. Sharma, and V. K. Saini, "Removal of cadmium and nickel from waste water using bagasse fly ash," J. Water Resour., vol. 37, no. 16, pp. 40384045, 2003.

[10] A. A. Ahmad, B. H. Hameed, and N. Aziz, "Adsorption of direct dye on palm ash: Kinetic and equilibrium modeling," J. Hazard. Mater., vol. 141, pp. 70-76, 2007.

[11] A. H. Abdullah, P. Anuark, Z. Zulkarnain, Z. H. Mohd, K. Dzulkefly, A. Faujan, and S. W. Ong, "Preparation and characterization of activated carbon from gelam wood bark (Melaleuca Cajuputi)," Malaysian J. Anal. Sci., vol. 7, no. 1, pp. 65-68, 2001.

[12] J. D. Babu, G. Kalyani, H. Joga-Rao, K. Y. Prasanna, and P. King, "Biosorption characteristics of lead onto bentonite clay as low-cost natural biosorbent," Int. J. Sci. Eng. Res., vol. 3, no. 8, pp. 8- 15, 2012.

[13] Y. S. Ho, "Selection of optimum sorption isotherm," Carbon, vol. 42, pp. 2115-2116, 2004.

[14] Y. S. Ho, J. F. Porter, and G. McKay, "Equilibrium isotherm studies for the sorption 
of divalent metal ions onto peat: copper, nickel and lead single component systems," Water Air Soil Pollut., vol. 141, pp. 1-33, 2002.

[15] K. Mariadas, G. Kalyani, H. R. Joga, P. Y. Kumar, and P. King, "The removal and equilibrium studies of cadmium by natural clay as adsorbent," Int. J. Sci. Eng. Res., vol. 3, no. 8, pp. 1-6, 2012.

[16] G. B. Krishna, and S. G. Susmita, "Adsorption of chromium (VI) from water by clays," Ind. Eng. Chem. Res., vol. 45, pp. 7232-7240, 2006.

[17] N. O. Omisanya, C. O. Folayan, S. Y. Aku, and S. S. Adefila, "Synthesis and characterization of zeolite for adsorption refrigeration application," Adv. Appl. Sci. Res., vol. 3, no. 6, pp. 3746-3754, 2012.

[18] O. A. Omokaye, Final report on the post impact assessment study of the Jesse oil spill/fire incident site, an unpublished investigation report submitted to pipeline and product marketing company (PPMC), 1999.

[19] I. Langmuir, "The constitution and fundamental properties of solids and liquids: Part I. Solids," J. Am. Chem. Soc., vol. 38, no. 2, pp. 2221-2295, 1916.

[20] A. Benmessaoud, D. Nibou, E-H. Mekatel, S. Amokrane, "A comparative study of the linear and non-linear methods for determination of the optimum equilibrium isotherm for adsorption of $\mathrm{Pb} 2+$ ions onto Algerian treated clay," Iran. J. Chem. Chem. Eng., vol. 39, no. 4, pp. 153-171, 2020.

[21] A. Khandelwal, N. Narayanan, E. Varghese, and S. Gupta, "Linear and nonlinear isotherm models and error analysis for the sorption of kresoxim-methyl in agricultural soils of India," Bull. Environ. Contam. Toxicol., vol. 104, pp. 503-510, 2020, https://doi.org/10.1007/s00128-020-02803-2

[22] D. Nibou, S. Khemaissia, S. Amokrane, M. Barkat, S. Chegrouche, and A. Mellah, "Removal of $\mathrm{UO}_{2}^{2+}$ onto synthetic $\mathrm{NaA}$ zeolite: Characterization, equilibrium and kinetic studies," Chem. Eng. J., vol. 172, no. 1, pp. 296-305, 2011.

[23] R. Sips, "On the structure of a catalyst surface," J. Chem. Phys., vol. 16, pp. 490$495,1948$.

[24] L. B. L. Lim, N. Priyantha, H. H. Cheng, and N. A. Zaidi, "Parkia speciosa (Petai) pod as a potential low-cost adsorbent for the removal of toxic crystal violet dye," Scientia Bruneiana, vol. 15, pp. 99-106, 2016.

[25] O. Redlich and D. L. Peterson, "A useful adsorption isotherm," J. Phys. Chem., vol. 63, pp. 1024-1026, 1959

[26] K. V. Kumar, S. Sivanesan, "Pseudo second order kinetics and pseudo isotherms for malachite green onto activated carbon: Comparison of linear and non-linear regression methods," J. Hazard. Mater., vol. 136, pp. 721-726, 2006.

[27] F-C. Wu, B-L. Liu, K-T. Wu, R-L. Tseng, "A new linear form analysis of Redlich-Peterson isotherm equation for the adsorptions of dyes," Chem. Eng. J., vol. 162, pp. 21-27, 2010.

[28] N. Ayawei, A. N. Ebelegi, and D. Wankasi, "Modeling and interpretation of adsorption isotherms," J. Chem., vol. 2017, Article ID 3039817, 2017, https://doi.org/10.1155/2017/3039817

[29] K. V. Kumar, K. Porkodi, and F. Rocha, "Isotherms and thermodynamic by linear and non-linear regression analysis for the sorption of methylene blue onto activated carbon; comparison of various error functions," $\mathrm{J}$. Hazard. Mater., vol. 151, pp. 794-804, 2008.

[30] K. Vasanth Kumar, K. Porkodi, and F. Rocha, "Comparison of various error functions in predicting the optimum isotherm by linear and non-linear regression analysis for the sorption of basic red 9 by activated carbon," J. Hazard. Mater., vol. 150, pp. 158-165, 2008.

[31] Z. L. Yaneva, B. K. Koumanova, and N. V. Georgieva, "Linear and nonlinear regression methods for equilibrium modeling of $p p$ Nitrophenol biosorption by rhizopus oryzae: Comparison of error analysis criteria," J. Chem., vol. 2013, Article ID 517631, 2013, http://dx.doi.org/10.1155/2013/517631

[32] Y. Mohammed, E. B. Farahnaz, K. B. Sepideh, D. J. Bahador, H. Soraya, R. M. Mohammad, and $\mathrm{A}$. C. Lugman, "Removal of $\mathrm{Ni}$ (II) from aqueous solution by an electric arc furnace slag using artificial neural network approach," Adv. Environ. Biol., vol. 7, no. 9, pp. 23032310, 2013.

[33] I. O. Oboh, "Evaluation of luffa cylindrical as a biosorbent in heavy metal sorption from aqueous solution," Ph.D. thesis, University of Benin, Benin City, Nigeria, 2011. 